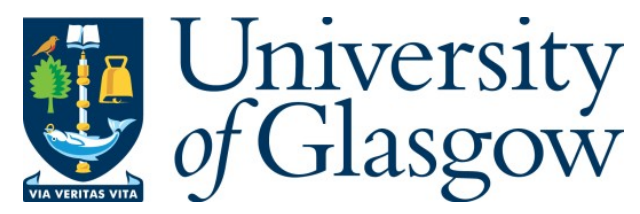

Kelliher, D. (2020) Assembling Cultures: Workplace Activism, Labour Militancy and Cultural Change in Britain's Car Factories, 1945-82 JACK SAUNDERS Manchester: Manchester University Press, 2019 x+298pp, ISBN 9781526133397 (£96). Contemporary British History. [Book Review] (Early Online Publication)

(doi: $10.1080 / 13619462.2020 .1715218$ )

This is the Author Accepted Manuscript.

There may be differences between this version and the published version. You are advised to consult the publisher's version if you wish to cite from it.

$\underline{\text { https://eprints.gla.ac.uk/207504/ }}$

Deposited on: 10 January 2020

Enlighten - Research publications by members of the University of Glasgow http://eprints.gla.ac.uk 


\section{Assembling Cultures: Workplace Activism, Labour Militancy and Cultural Change in Britain's Car Factories, 1945-82}

\section{JACK SAUNDERS}

Manchester, Manchester University Press, 2019

x+298 pp., ISBN978 1526133397 (£96)

Jack Saunders' excellent new book charts the shifting dynamics of workplace activism within post-war Britain's car factories. The first chapter explores public discourses surrounding car workers and trade unionism more generally, emphasising the increasingly vitriolic reporting of the labour movement from the mid-1950s onwards. This overview helps demonstrate how factory culture often diverged from dominant social attitudes. The core of Saunders' book, however, places workplace activism to the forefront of post-war British history. Through sustained analysis of the practicalities of organising the factories, Saunders historicises working-class agency. The book charts the establishment of strong shopfloor organisation in the 1950s and 1960s, the greater formalisation and coordination of car factory trade unionism by the 1970s, and the subsequent decline of labour militancy into the 1980s.

The car industry offers a compelling case study because it lacked a pre-war tradition of trade union organisation. Indeed, Saunders emphasises how in the immediate post-war period, car workers tended to collectively enforce workplace discipline. The book traces the patient effort through which a cohort of car workers established shop steward influence, notably through activism around piece rates, the pace of production, and the arbitrary disciplinary power of supervisors. Mobilisation centred on issues that were limited in scale and where victories were achievable; successes helped embed the idea that direct action brought concrete gains. 
Labour historians have rightly dismissed lazy caricatures of overbearing trade unions, but at times this can go too far in denying the power gained through workplace organisation. Shopfloor militancy gave workers a direct - if uneven and conditional - say in their everyday lives. Contrary to popular myth, such union organisation substantially deepened democracy. Saunders emphasises the decentralised participatory practices of factory organising, particularly in the 1960s. While the mass meeting would dominate images of trade unionism in the 1970s, small regular shop meetings enabled a direct relationship between shop stewards and ordinary members that kept workers engaged and gave significant legitimacy to trade unions.

In contrast to narratives of a rise of individualism and privatism in post-war Britain, Saunders highlights the production of new forms of solidarity and collective modes of organising. 'In many factories', he argues, 'workshop-based collectivism became the dominant norm, and self-regarding individualism came to be seen as pathological' (pp.79-80). This norm was formalised in the development of the closed shop, where union membership was mandatory. While the book acknowledges the dark side to the enforcement of such norms - the bullying, harassment and so on directed at transgressors - the strength of this collectivism brought significant gains.

Saunders' close focus on the workplace is welcome and it would be unfair to suggest the book should do more. It does spark some thoughts, though, about the relationship between the factory and the world beyond. To what extent were the differences in trade union organisation between factories embedded in the wider industrial and political cultures of particular localities, regions and nations? The book suggests, for instance, that car workers in Coventry may have plugged into a broader trade union tradition in the area. Wright, Phillips and Tomlinson's work relating the Linwood car plant in the 1960s and 1970s to Scotland's political divergence from England is suggestive in this respect. 
Saunders convincingly argues that attempts at overt politicisation of workplace trade unionism were largely resisted by the membership. However, there are hints here - for example in relation to the 1972 Industrial Relations Bill - that factory activism could feed into a broader labour movement. Another example that comes to mind is the mass walkout of Birmingham car workers to support the miners' picket at Nechells gas works - the 'Battle of Saltley Gates' - during the 1972 coal dispute. It was, of course, an exceptional moment, but such events suggest that a broader class consciousness may have developed through the hyper-localised organising that Saunders details.

There is a tension in the book, but a productive one I think, between agency and culture. Saunders repeatedly emphasises that workplace activism shaped ideas of what was considered common sense and reasonable within the factory. The book draws upon Bourdieu's concept of habitus to emphasise how practices such as shop steward organisation, worker consultation, and sectional strikes became embedded in the culture of car factories. The sense that practices became normalised is crucial. While some prominent activists were members of the revolutionary left, their wider influence in the workplace depended not on an avowed militancy but rather the opposite: a worldview in which wildcat strikes were considered relatively ordinary.

Yet the picture created by the book feels more dynamic and unstable than Bourdieu's theory can imply. This is largely not a problem in practice, but it feels a greater issue when it comes to explaining the decline of workplace militancy. Saunders argues that this was an uneven and incomplete processes. Against a focus on deindustrialisation and a rise of Thatcherite individualism, Saunders emphasises issues more internal to union organising. A certain amount of bureaucratisation and incorporation of union activists helped create distance between them and members in the 1970s, but most of all - the book suggests - a certain war weariness set it. The argument is convincing up to point and offers a corrective to excessively 
deterministic readings of the period. However, if the union cultures were as deeply embedded as the concept of habitus suggests, this does not feel quite enough.

Much more could be said about a book which combines richness in detail with a compelling central argument. Saunders' work makes a substantial contribution not just to studies of the labour movement but to contemporary British history more widely, and beyond the discipline on the importance of historicising working-class agency. It is also, ultimately, a hopeful book: it emphasises the possibilities for building new bonds of solidarity, democratic forms of organisation, and power in the workplace. All of which we will be in desperate need of in the coming years.

Diarmaid Kelliher

University of Glasgow

Rm 516, School of Geographical and Earth Sciences

East Quad, Main Building

University of Glasgow

Glasgow

G12 8QQ 